\title{
Faktor Keuangan Dan Financial Distress
}

\author{
Desti Eka Putri ${ }^{1}$, Dirvi Surya Abbas $^{2}$ \\ 1,2,3. Universitas Muhammadiyah Tangerang \\ email korespondensi: desti.putri2312@gmail.com
}

\begin{abstract}
Abstrak: Penelitian ini bertujuan untuk menganalisis secara simultan dan parsial pengaruh Likuiditas, Leverage, Pertumbuhan Penjualan, Kepemilikan Institusional, dan Komisaris Independen terhadap Financial Distress sektor Consumer Goods Industry (CGI) yang terdaftar di BEI pada Periode 2016-2018. Metode sampling yang digunakan dalam penelitian ini adalah metode purposive sampling yaitu metode pengambilan sampel sesuai kriteria tersebut. Perusahaan yang mencapai kriteri daam penelitian ini sebanyak 11 perusahaan Consumer Goods Industry (CGI) di BEI pada periode 20162018. Analisis yang digunakan yaitu analisis regresi data panel untuk melihat pengaruh variabel independen terhadap variabel dependen baik secara bersama-sama aupun secara individu yang didahului oleh uji asumsi klasik yaitu uji chow, uji hausman, dan uji lagrange multipier. Pengujian hipotesis dilakukan dengan menggunakan uji F, uji RSquared dan uji T. Hasil penelitian ini memberikan informasi bahwa Leverage, Pertumbuhan Penjualan, Kepemilikan Institusional, dan Komisaris Independen tidak berpengaruh signifikan terhadap Financial Distress pada perusahaan Consumer Goods Industry (CGI) yang terdaftar di Bursa Efek Indonesia (BEI), sedangkan Likuiditas berpengaruh signifikan terhadap Financial Distress pada perusahaan Consumer Goods Industry (CGI) yang terdaftar di Bursa Efek Indonesia (BEI).
\end{abstract}

Kata kunci : likuiditas, leverage, pertumbuhan penjalan, kepemilikan institusional, dan komisaris independen.

Menurut (Wahyu,2009) persaingan antara perusahaan satu dan yang lainnya semakin lama semakin ketat sehingga menyebabkan biaya yang akan dikeluarkan oleh perusahaan akan semakin tinggi, hal tersebut akan mempengaruhi kinerja perusahaan. Apabila perusahaan tidak mampu bersaing maka perusahaan tersebut akan mengalami kerugian, sehingga pada akhirnya mengakibatkan perusahaan mengalami financial distress. Masalah keuangan perusahaan apabila dibiarkan tidak ada antisipasi untuk mengatasinya dapat mengakibatkan terjadinya kebangkrutan. Dalam penelitian (Luciana,2003), suatu perusahaan yang dikategorikan mengalami financial distress adalah apabila perusahaan tersebut mengalami laba operasi negatif selama dua tahun berturut-turut. Perusahaan menunjukkan telah terjadi tahap penurunan kondisi keuangan suatu perusahaan. Apabila tidak ada tindakan perbaikan yang dilakukan manajemen perusahaan maka perusahaan dapat terindikasi mengalami kebangkrutan.

Likuiditas sebuah perusahaan diprediksi akan memengaruhi agresivitas pajak perusahaan. Perusahaan yang memiliki likuiditas tinggi menggambarkan memiliki arus kas yang baik sehingga perusahaan tersebut tidak enggan untuk membayar seluruh kewajibannya termasuk membayar pajak sesuai dengan aturan yang berlaku. Sebaliknya, Bradley (1994) serta Siahaan (2005) menyatakan perusahaan yang memiliki likuiditas rendah akan tidak taat terhadap pajak guna mempertahankan arus kas perusahaan dari pada harus membayar pajak. 
Rasio Leverage dipakai untuk mengukur kemampuan perusahaan guna memenuhi kewajiban jangka panjangnya dengan modal atau ekuitas yang dimiliki, yang berarti bahwa leverage tidak berpengaruh signifikan pada financial distress menurut Ni Wayan Krisnayanti Arwinda Putri dan $\mathrm{Ni}$ Kt. Lely A. Merkusiwati (2014)

Tetapi, menurut Dessy Karinasari (2016) menilai semakin tinggi rasio leverage suatu perusahaan maka perusahaan akan semakin rendah mengalami financial distress. Maka Leverage berpengaruh negative terhadap Financial Distress. Pertumbuhan penjulan menggambarkan keberhasilan investasi periode masa lalu dan dapat dijadikan sebagai perkiraan pertumbuhan masa yang akan datang. Pertumbuhan penjualan merupakan pertunjuk permintaan dan daya saing perusahaan dalam satu industri.

Berdasarkan Penelitian terdahulu menurut (Zuhria \& Riharjo, 2016) dan (Mulyati, 2016).Pertumbuhan penjualan berpengaruh terhadap Financial Distress sedangkan menurut (Damayanti \& Hartini, 2013) bertentangan yaitu pertumbuhan penjualan tidak berpegaruh apapun terhadap Financial Distress. Menurut Faizal (2004), perusahaan dengan kepemilikan institusional yang besar mengindikasikan kemampuannya untuk memonitor manajemen. Semakin besar kepemilikan institusional maka semakin efisien pemanfaatan aktiva perusahaan dan diharapkan juga dapat bertindak sebagai pencegahan terhadap pemborosan yang dilakukan oleh manajemen.

Kepemilikan institusional adalah proporsi kepemilikan saham pada akhir tahun yang dimiliki oleh lembaga, seperti asuransi, bank atau institusi lain. (Tarjo, 2008). Kepemilikan institusional memiliki arti penting dalam memonitor manajemen. Adanya kepemilikan oleh institusional akan mendorong peningkatan pengawasan yang lebih optimal

Komisaris Independen sangat dibutuhkan sikap indepedensinya dalam menjalankan tugasnya, namun terkadang seorang komisaris independen memiliki sikap independensi yang kurang, yang dapat mengakibatkan lemahnya pengawasan terhadap kinerja manajemen perusahaan, sehingga tidak akan memiliki pengaruh terhadap terjadinya financial distress Ni Wayan Krisnayanti Arwinda Putri dan Ni Kt. Lely A. Merkusiwati (2014).Sedangkan menurut Novia Nurmayati (2017) Komisaris Independen berpengaruh positif terhadap Financial Distress.

Fenomena yang terjadi terhadap Financial Distress secara parsial maupun simultan pasa perusahaan Cunsumer Goods Industry (CGI) terdaftar di BEI periode 20162018. Populasi dalam penelitian ini adalah perusaaan manufaktur sub sektor makanan dan minuman yang terdaftar di BEl periode 2016-2018 dengan total populasi 11perusahaan.

Berdasarkan latar belakang diatas, maka pada penelitian ini peneliti ingin menuji kembali apakah variabel-variabel yang digunakan oleh peneliti nantinya terdapat perbedaan dari hasil penelitian terdahulu. Berdasarkan fenomena dan Research GAP maka peneliti mengambil judul 
"Pengaruh Likuiditas, Leverage, Pertumbuhan Penjualan, Kepemilikan Institusional, dan Komisaris Independen terhadap Financial Distress".

\section{METODE}

Jenis data yang digunakan dalam penelitian ini menggunakan data sekunder (secondary data), yakni data kuantitatif yang diambil dari 51 perusahaan yang merupakan seluruh perusahaan sektor consumer goods industry telah terdaftar di Bursa Efek Indonesia (BEl) selama periode 2016-2018. Data yang digunakan yaitu data laporan keuangan tahunan dalam kurun waktu 2016-2018 yang diakses langsung dari situs Bursa Efek Indonesia (BEI) www.idx.co.id. Perusahaan Sektor Consumer Goods Industry dipilih karena terdapat perusahaan yang paling banyak mengalami laba operasi negatif selama tahun 2016 hingga 2018. Hal ini mengindikasikan suatu kinerja perusahaan yang kurang baik atau merupakan suatu tahap penurunan kondisi keuangan perusahaan sehingga dapat mempengaruhi kualitas laba perusahaan.

Teknik pengambilan sampel dalam penelitian ini dilakukan dengan menggunakan teknik Purpose Sampling, yang berarti pemilihan sampel berdasarkan kriteria tertentu. Jumlah perusahaan yang memenuhi kriteria adalah sebanyak 24 perusahaan selama periode 2016-2018, sehingga jumlah data adalah 51 data. Dari 51 data tersebut jumlah data yang digunakan dalam penelitian ini adalah 11 perusahaan atau sebanyak 33 data. Dibawah ini adalah kriteria sampel yang digunakan adalah sebagai berikut:

a) Perusahaan sektor consumer goods industry yang terdaftar di Bursa Efek Indonesia (BEI) selama periode 2016-2018.

b) Perusahaan sektor consumer goods industry yang melaporkan laporan keuangan tahunan secara berturut-turut selama periode 20162018.

c) Perusahaan sektor consumer goods industry yang mengalami keuntungan selama berturut-turut selama periode penelitian.

d) Perusahaan sektor consumer goods industry yang menyampaikan data laporan keuangan menggunakan mata uang rupiah secara berturut-turut selama periode penelitian.

Perusahaan yang menyampaikan data secara lengkap selama periode penelitian serta berkaitan dengan variabel likuiditas, leverage, pertumbuhan penjualan, kepemilikan institusional, komisaris independen.

\section{Financial Distress ( $Y$ )}

Rasio keuangan menurut Ika (2011.p:104), rasio merupakan alat untuk menyatakan pandangan terhadap kondisi yang mendasari, dalam hal ini adalah kesulitan keuangan kondisi (financial distess) perusahaan. Rasio rasio yang diinterpretasikan are yang memerlukan investasi lebih lanjut. James C Van Horne dalam Kasmir (2012.p:104), menyatakan bahwa rasio keuangan merupakan indeks yang menghubungkan dua angka akuntansi 
yang diperoleh dengan membagi satu angka dengan angka lain. Rasio keuangan digunakan untuk mengevaluasi kondisi keuangan dan kinerja perusahaan, sehingga dari hasil rasio keuangan ini akan terlihat kondisi kesehatan perusahaan tersebut. Menurut Atika dkk (2013) Analisis rasio keuangan dapat menjadi salah satu alat memprediksi kesulitan keuangan financial distress, yang digunakan untuk mengukur kesehatan perusahaan. Analisis rasio keuangan mengenai hubungan data keuangan dan pos- pos dalam neraca atau laba rugi untuk mengetahui baik atau buruk posisi keuangan dan kinerja perusahaan tersebut.

Financial Distress sebagai variabel dependen dalam pnelitian ini diukur dengan menggunakan rumus Altman ZScore yang dapat dihitung sebagai berikut :

\section{Likuiditas $\left(\mathbf{X}_{1}\right)$}

$$
Z=1,2 T^{1}+1,4 T^{2}+3,3 T^{3}+0,6 T^{4}+0,99 T^{5}
$$

Rasio Lancar (current ratio) adalah ukuran yang bias diunakan atas kemampuan persahaan untuk membayar utang jangka pendek, kesanggupan suatu perusahaan untuk menutupi kebutuhan utang ketika jatuh tempo. Menurut Libby et,al, (2007) dalam (SUSANTI, 2016) adapun rumus rasio lancar sebagai berikut :

$$
C R=\frac{\text { Aktiva Lancar }}{\text { Hutang Lancar }} \times 100 \%
$$

\section{Leverage $\left(X_{2}\right)$}

Leverage dihitung dengan melihat proposi besarnya aset yang dibiayai oleh hutang. Peneliti mengacu pada penelitian yang dilakukan oleh (Susanto dan Ramadhani, 2016). Adapun rumus Leverage sebagai berikut :

$$
D E R=\frac{\text { Total Hutang }}{\text { Total Ekuitas }} \times 100 \%
$$

\section{Pertumbuhan Penjualan $\left(\mathbf{X}_{3}\right)$}

Perusahaan dengan kualitas penjualan dan lab ayang tinggi biasanya perusahaan tersebut menggunakan utang sebagai sumber dana dari luar yang lebih besar daripda perusahaan-perusahaan yang tingkat penjualannnya rendah. Rasio Growth Sales menurut Harahap (2008, h.309) dalam (Darmayangti \& Hatrini, 2013) dirumuskan sebagai berikut :

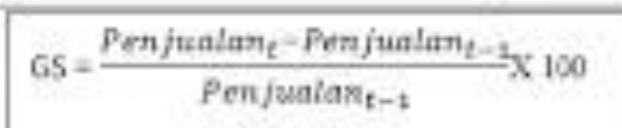

\section{Kepemilikan Institusional $\left(\mathbf{X}_{4}\right)$}

Kepemilikan institusional dapat diukur dengan menggunakan indikator persentase jumlah saham yang dimiliki pihak institusional dari seluruh jumlah saham perusahaan (Boediono, 2005). 
Rumus menghitung kepemilikan institusional :

$$
I N S T=\frac{\text { Jumlah saham yang dimiliki institusional }}{\text { Total Keseluruhan Saham }} X 100
$$

Komisaris Independen $\left(X_{5}\right)$

Independensi Dewan Komisaris Independensi dewan komisaris merupakan proporsi jumlah anggota dewan komisaris dari keseluruhan dewan komisaris di dalam perusahaan. Untuk mengukurnya dilakukan dengan cara berikut:

$$
\frac{\Sigma \text { komisaris independen }}{\Sigma \text { anggota dewan komisaris }} \times 100 \%
$$

\section{HASIL}

\section{Analisis Deskriptif Variabel Penelitian}

Analisis deskriptif atau disebut dengan statistil deskriptif emberikan gambaran ataupun deskripsi mengenai variabelvariabel penelitian yakni terdiri dari Financial Distress, Likuiditas, Leverage, pertumbuhan Penjualan, Kepemilikan Institusional, dan Komisaris Independen

\begin{tabular}{|c|c|c|c|c|c|}
\hline & Y & LIKUIDITAS & LEVERAGE & PERP & KEPINS \\
\hline Mean & 28960.09 & 31945.42 & 11424179 & 9180.970 & 6131.12 \\
\hline Median & 29156.00 & 26784.00 & 2961724. & 9482.000 & 6950.00 \\
\hline Maximum & 73953.00 & 64759.00 & $2.71 E+08$ & 11907.00 & 9650.00 \\
\hline Minimum & 2231.000 & 10518.00 & 1405567. & 823.0000 & 514.000 \\
\hline Std. Dev. & 13636.72 & 16434.19 & 46690424 & 1981.177 & 2630.60 \\
\hline Skewness & 0.993828 & 0.409402 & 5.467229 & -2.599754 & -0.88020 \\
\hline Kurtosis & 5.459325 & 1.800900 & 30.93999 & 11.42198 & 2.95693 \\
\hline Jarque-Bera & 13.74870 & 2.898887 & 1237.782 & 134.7014 & 4.26372 \\
\hline Probability & 0.001034 & 0.234701 & 0.000000 & 0.000000 & 0.11861 \\
\hline Sum & 955683.0 & 1054199. & $3.77 \mathrm{E}+08$ & 302972.0 & 202327. \\
\hline Sum Sq. Dev. & $5.95 E+09$ & $8.64 E+09$ & $6.98 E+16$ & $1.26 \mathrm{E}+08$ & $2.21 \mathrm{E}+\mathrm{O}$ \\
\hline Observations & 33 & 33 & 33 & 33 & 33 \\
\hline
\end{tabular}

Tabel 1. Analisis Statistik Deskriptif

\section{Pemilihan Model Regresi Data Panel Analisis Regresi Data Panel}

Metode yang dilakukan dalam penelitian ini adalah uji regresi data panel (pool) yaitu daa yang merupakan gabungan antara data seksi silang (Cross Section) dengan data runtun waktu (Time Series). 
Tabel 2. Uji Chow

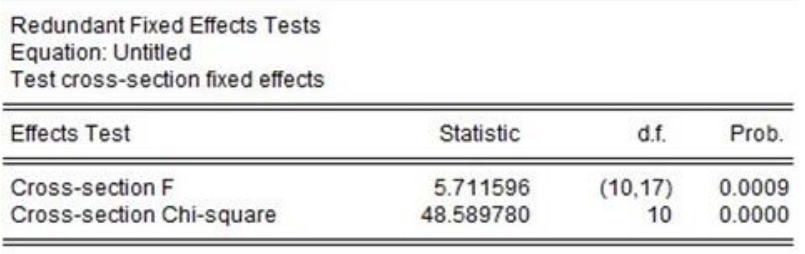

Cross-section fixed effects test equation:

Dependent Variable: $Y$

Method: Panel Least Squares

Sumber: Hasil Olahan Eviews 10.0, 2020.

\section{Tabel 3. Uji Hausman}

Correlated Random Effects - Hausman Test

Equation: Untitled

Test cross-section random effects

\begin{tabular}{lrrr}
\hline \hline Test Summary & Chi-Sq. Statistic & Chi-Sq. d.f. & Prob. \\
\hline \hline Cross-section random & 9.789984 & 5 & 0.0814 \\
\hline
\end{tabular}

Cross-section random effects test comparisons:

\begin{tabular}{crrrr} 
Variable & Fixed & Random & $\operatorname{Var}$ (Diff.) & Prob. \\
\hline \hline LIKUIDITAS & 0.637460 & 0.535534 & 0.073003 & 0.7060 \\
LEVERAGE & -0.000018 & -0.000033 & 0.000000 & 0.0317 \\
PERP & -1.737291 & -1.149545 & 0.258301 & 0.2475 \\
KEPINS & -3.074444 & -1.394489 & 0.663633 & 0.0392 \\
KOMIND & -6.382187 & -1.745395 & 13.114578 & 0.2004 \\
\hline
\end{tabular}

Sumber: Hasil Olahan Eviews 10.0, 2020.

\section{Tabel 4. Uji Lagrange Multiplier}

\begin{tabular}{|c|c|c|c|}
\hline $\begin{array}{l}\text { Null (no rand. effect) } \\
\text { Alternative }\end{array}$ & $\begin{array}{l}\text { Cross-section } \\
\text { One-sided }\end{array}$ & $\begin{array}{c}\text { Period } \\
\text { One-sided }\end{array}$ & Both \\
\hline Breusch-Pagan & $\begin{array}{l}6.907376 \\
(0.0086)\end{array}$ & $\begin{array}{l}1.572313 \\
(0.2099)\end{array}$ & $\begin{array}{l}8.479690 \\
(0.0036)\end{array}$ \\
\hline Honda & $\begin{array}{l}2.628189 \\
(0.0043)\end{array}$ & $\begin{array}{c}-1.253919 \\
(0.8951)\end{array}$ & $\begin{array}{l}0.971755 \\
(0.1656)\end{array}$ \\
\hline King-Wu & $\begin{array}{l}2.628189 \\
(0.0043)\end{array}$ & $\begin{array}{c}-1.253919 \\
(0.8951)\end{array}$ & $\begin{array}{c}-0.071713 \\
(0.5286)\end{array}$ \\
\hline GHM & - & - & $\begin{array}{l}6.907376 \\
(0.0122)\end{array}$ \\
\hline
\end{tabular}

Sumber: Hasil Olahan Eviews 10.0, 2020. 


\section{Kesimpulan Model}

Hasil pengujian disajikan dalam tabel sebagai berikut

Tabel 5. Kesimpulan Pemilihan Model Regresi

\begin{tabular}{|c|l|c|c|}
\hline No & Metode & Pengujian & Hasil \\
\hline 1 & Uji Chow & CEM VS REM & FEM \\
\hline 2 & $\begin{array}{l}\text { Uji } \\
\text { Hausman }\end{array}$ & REM VS FEM & REM \\
\hline 3 & $\begin{array}{l}\text { Uji } \\
\text { Lagrange } \\
\text { Multiplier }\end{array}$ & CEM VS REM & REM \\
\hline
\end{tabular}

Jika dilihat dari ketiga pengujian yang sudah dilakukan maka dapat disimpulkan bahwa Model Regresi Data Panel yang akan digunakan dalam Uji Hipotesis dan Persamaan Regresi Data Panel adalah model Random Effect Model (CEM), maka diperlukan Uji Asumsi Klasik.

\section{Uji Hipotesis}

\section{Uji Signifikasi simultan(Uji Statistik F)}

Untuk menguji apakah model yang digunakan baik, ,maka dapat dilihat dari signifikasi pengaruh variabel bebas yaitu Likuiditas, Leverage, pertumbuhan Penjualan, Kepemilikan Institusional, dan Komisaris Independen terhadap variabel terkait yaitu Financial Distress.

Tabel 4. Uji F

\begin{tabular}{|c|c|c|c|c|}
\hline Variable & Coefficient & Std. Error & t-Statistic & Prob. \\
\hline c & 38034.77 & 16312.17 & 2.331680 & 0.0274 \\
\hline LIKUIDITAS & 0.535534 & 0.231363 & 2.314692 & 0.0285 \\
\hline LEVERAGE & $-3.29 E-05$ & $3.15 \mathrm{E}-05$ & -1.045048 & 0.3053 \\
\hline PERP & -1.149545 & 0.852531 & -1.348392 & 0.1887 \\
\hline KEPINS & -1.394489 & 1.191924 & -1.169948 & 0.2522 \\
\hline KOMIND & -1.745395 & 2.726281 & -0.640211 & 0.5274 \\
\hline \multicolumn{5}{|c|}{ Effects Specification } \\
\hline & & & S.D. & Rho \\
\hline Cross-section random & & & 10264.58 & 0.6775 \\
\hline Idiosyncratic random & & & 7081.813 & 0.3225 \\
\hline \multicolumn{5}{|c|}{ Weighted Statistics } \\
\hline R-squared & 0.344953 & \multirow{5}{*}{\multicolumn{2}{|c|}{$\begin{array}{l}\text { Mean dependent var } \\
\text { S.D. dependent var } \\
\text { Sum squared resid } \\
\text { Durbin-Watson stat }\end{array}$}} & 10716.75 \\
\hline Adjusted R-squared & 0.223649 & & & 8721.247 \\
\hline S.E. of regression & 7684.361 & & & $1.59 \mathrm{E}+09$ \\
\hline F-statistic & 2.843689 & & & 1.181194 \\
\hline Prob(F-statistic) & 0.034493 & & & \\
\hline \multicolumn{5}{|c|}{ Unweighted Statistics } \\
\hline R-squared & 0.177438 & Mean depenc & nt var & 28960.09 \\
\hline Sum squared resid & $4.89 E+09$ & Durbin-Watsc & stat & 0.384735 \\
\hline
\end{tabular}

Sumber: Hasil Olahan Eviews 10.0, 2020

Berdasarkan hasil di atas menunjukkan bahwa nilai F-Statistik sebesar 2,843689 dan nilai Probabilitas F statistik 0,034493 maka dapat disimpulkan bahwa Ha diterima. Dengan demikian penelitian layal untuk di lanjutkan karena variable- variable independent berpengaruh yaitu Likuditas sebesar 0,0285 kurang dari 0,05 terhadap Financial Distress 


\section{Uji Signifikasi Simultan (Uji Statistik T)}

Untuk mengetahui hipotesis dalam penelitian, maka dapat digunakan uji-t dan diuji apakah masing-masing variabel bebas yaitu Likuiditas, Leverage, pertumbuhan Penjualan, Kepemilikan Institusional, dan Komisaris Independen berpengaruh secara signifikan terhadap variabel terkait yaitu Financial Distress. 3. Uji Koefisien Determinasi (R2) Koefisien determinasi dapat mengukur seberapa jauh kemampuan model variabel Likuiditas, Leverage, pertumbuhan Penjualan, Kepemilikan Institusional, dan Komisaris Independen dalam menerangkan dan menjelaskan variabel dependen. Nilai koefisien daterminasi yang dapat dikelompokkan kecil berarti keahlian variabel independent membantu hamper semua informasi yang dibutuhkan untuk memprediksi variasi variabel dependen (Imam Ghozali, 2011).

Tabel 4. Uji Koefisien Determinasi R2

\begin{tabular}{ccccc}
\hline Variable & Coefficient & Std. Error & t-Statistic & Prob. \\
\hline C & 38034.77 & 16312.17 & 2.331680 & 0.0274 \\
LIKUIDITAS & 0.535534 & 0.231363 & 2.314692 & 0.0285 \\
LEVERAGE & $-3.29 \mathrm{E}-05$ & $3.15 \mathrm{E}-05$ & -1.045048 & 0.3053 \\
PERP & -1.149545 & 0.852531 & -1.348392 & 0.1887 \\
KEPINS & -1.394489 & 1.191924 & -1.169948 & 0.2522 \\
KOMIND & -1.745395 & 2.726281 & -0.640211 & 0.5274 \\
\hline \hline & Effects Specification & & \\
& & & S.D. & Rho \\
\hline \hline Cross-section random & & & 10264.58 & 0.6775 \\
Idiosyncratic random & & & 7081.813 & 0.3225 \\
\hline \hline & Weighted Statistics & & \\
\hline \hline R-squared & 0.344953 & Mean dependent var & 10716.75 \\
Adjusted R-squared & 0.223649 & S.D. dependent var & 8721.247 \\
S.E. of regression & 7684.361 & Sum squared resid & $1.59 \mathrm{E}+09$ \\
F-statistic & 2.843689 & Durbin-Watson stat & 1.181194 \\
Prob(F-statistic) & 0.034493 & & \\
\hline \hline
\end{tabular}

Sumber: Hasil Olahan Eviews 10.0, 2020.

Berdasarkan hasil diatas menunjukkan bahwa nilai Probabilitas 0,034493 dan nilai Adjusted R-squared sebesar 0,223649 yang artinya bahwa variabel perubahan naik turunnya Financial Distress dapat dijelaskan oleh Likuiditas, Leverage, Pertumbuhan Penjualan, Kepemilikan Institusional, dan Komisaris Independen sebesar 22,36\% sementara sisanya sebesar $77,64 \%$ dijelaskan pada variabel-variabel lain yang tidak ditelti dalam penelitian.

\section{KESIMPULAN}

Berdasarkan hasil analisis dan pembahasan data, peneliti memperoleh kesimpulan yang dapat diambil dari penelitian mengenai pengaruh Likuiditas, Leverage, Pertumbuhan Penjualan, Kepemilikan Institusional, dan Komisaris Independen yang teradaftar di BEI tahun 2016-2018 sebagai berikut :

1. Dalam penelitian ini Likuiditas berpengaruh positif terhadap Financial Distress pada perusahaan Consumer Goods Industry (CGl) yang terdafatar di 
Bursa Efek Indonesia (BEI) tahun 20162018. Hal ini ditunjukkan dari perhitungan uji T dari nilai Coefficient sebesar 0,535534. Maka dapat disimpulkan bahwa Likuiditas dalam penelitian ini memiliki pengaruh terhadap Finaancial Distress.

2. Dalam penelitian ini Leverage berpengaruh negatif terhadap Financial Distress pada perusahaan Consumer Goods Industry (CGI) yang terdafatar di Bursa Efek Indonesia (BEI) tahun 20162018. Hal ini ditunjukkan dari perhitungan uji $\mathrm{T}$ dari nilai Coefficient sebesar 3,299999.

3. Pertumbuhan Penjualan dalam penelitian ini berpengaruh negatif terhadap Financial Distress pada perusahaan Consumer Goods Industry (CGI) yang terdafatar di Bursa Efek Indonesia (BEI) tahun 2016-2018. Hal ini ditunjukkan dari perhitungan uji $\mathrm{T}$ dari nilai Coefficient sebesar $-1,149545$

4. Kepemilikan Institusional dalam penelitian ini berpengaruh negatif terhadap Financial Distress pada perusahaan Consumer Goods Industry (CGI) yang terdafatar di Bursa Efek Indonesia (BEI) tahun 2016-2018. Hal ini ditunjukkan dari perhitungan uji $\mathrm{T}$ dari nilai Coefficient sebesar $-1,394489$.

5. Komisaris Independen dalam penelitian ini berpengaruh negatif terhadap Financial Distress pada perusahaan Consumer Goods Industry (CGI) yang terdafatar di Bursa Efek Indonesia (BEI) tahun 2016-2018. Hal ini ditunjukkan dari perhitungan uji T dari nilai

Coefficient sebesar $-1,745395$.

Berdasarkan simpulan yang teah dikemukakan di atas, maka saran yang diajukan yaitu sebelum melakukan penelitian sebaiknya mengestimasi periode terkait, minimal 3 tahun agar yang digunakan agar mempermudah peneliti untuk mengerjakan sampel, dan penelitian berikutnya diharapkan dapat menambah jumlah sampel dan mewakili masingmasing sektor industry secra menyeluruh keadaan perusahaan go public di Indonesia.

\section{DAFTAR PUSTAKA}

Cinantya, I., \& Merkusiwati, N. (2015). Pengaruh Corporate Governance, Financial Indicators, Dan Ukuran Perusahaan Pada Financial Distress. E-Jurnal Akuntansi, 10(3), 897-915

Asfali, I. (2019). Pengaruh Profitabilitas, Likuiditas, Leverage, Aktivitas, Pertumbuhann Penjualan Terhadap Financial Distress Perusahaan Kimia. Jurnal Ekonomi Dan Manajemen, 20(2), 56-66.

Srikalimah. (2017). JURNAL AKUNTANSI \& EKONOMI FE. UN PGRI Kediri Vol. 2 No. 1, Maret 2017. 2(1), 43-66.

Hanafi, I. (2018). Prediksi Financial Distress Perusahaan Manufaktur yang Terdapat di Bursa Efek Indonesia. Universitas Diponegoro, 4(1), 26-51.

Nurmayant Nugroho, A. A., Baridwan, Z., \& Mardiati, E. (2018). Pengaruh 
Profitabilitas, Likuiditas, Leverage, dan Corpo-Rate Governance Terhadap Kecurangan Laporan Keuangan, Serta Financial Distress Sebagai Variabel Intervening. Media Trend, 13(2), 219. https://doi.org/10.21107/mediatrend.v13i2.4065

i, N. (2017). Pengaruh Profitabilitas, Likuiditas, Leverage Dan Corporate Governance Terhadap Pengungkapan Financial Distress Perusahaan Manufaktur Makanan \& Minuman Serta Peralatan Rumah Tangga Yang Terdaftar Di Bei Tahun 2010-2015. Skripsi. FAKULTAS EKONOMI DAN BISNIS. UNIVERSITAS MUHAMMADIYAH SURAKARTA, 0-11.

Karinasari, D. (2014). Pengaruh Profitabilitas, Likuiditas, Leverage dan Pertumbuhan Penjualan Terhadap Kondisi Financial Distress Pada Perusahaan Jasa Transportasi Periode 2011-2014. Artikel IImiah Sekolah Tinggi IImu Ekonomi Perbanas. Putri, N. W. K. A., \& Merkusiwati, N. K. L. A. (2014). Pengaruh Mekanisme Corporate Governance, Likuiditas, Leverage, Dan Ukuran Perusahaan Pada Financial Distress. E-Jurnal Akuntansi, 7(1), 93106.

Nugroho, A. A., Baridwan, Z., \& Mardiati, E. (2018). Pengaruh Profitabilitas, Likuiditas, Leverage, dan Corpo-Rate Governance Terhadap Kecurangan Laporan Keuangan, Serta Financial Distress Sebagai Variabel Intervening. Media Trend, 13(2), 219. https://doi.org/10.21107/mediatrend.v13i2.4065

Widarjo, W., \& Setiawan, D. (2013). Pengaruh Rasio Keuangan Terhadap Kondisi Financial Distress Perusahaan Otomotif. Jurnal Bisnis Dan Akuntansi, 11(2), 107-119. https://doi.org/10.1016/j.intele.2017.03.006 